\title{
PROCUREMENT CHALLENGES IN THE SOUTH AFRICAN PUBLIC SECTOR
}

\author{
INTAHER M AMBE* \\ JOHANNA A BADENHORST-WEISS \\ *ambeim@unisa.ac.za \\ Department of Business Management \\ University of South Africa (Unisa)
}

\begin{abstract}
This article reports on an exploration of challenges experienced in the field of procurement within the South African public sector. To institute procurement best practices, a supply chain management system was adopted in South Africa in 2003. The procurement process was granted constitutional status and has been used to address past inequitable policies and practices. It promotes aims which are, arguably, secondary to the primary aim of procurement. For the exploration, a conceptual analytical approach was employed and some of the key guiding pillars of public procurement in South Africa divulged. The challenges restraining effective and efficient implementation of public procurement are also revealed. The article concludes by recommending the development of competency through customised (separate) training materials and programmes, the involvement of stakeholders in the bidding process and the employment of good strategic sourcing practices.
\end{abstract}

\section{INTRODUCTION}

Public procurement operates in an environment of increasingly intense scrutiny driven by technology, programme reviews, and public and political expectations for service improvements (Bolton, 2006; Eyaa \& Oluka, 2011). Currently, in South Africa, procurement is of particular significance in the public sector and has been used as a policy tool due to the discriminatory and unfair practices during apartheid (Bolton, 2006). Procurement is central to the government service delivery system, and promotes aims which are, arguably, secondary to the primary aim of procurement such as using procurement to promote social, industrial or environmental policies (Cane, 2004). Prior to 1994, public procurement in South Africa was geared towards large and established contractors. It was difficult for new contractors to participate in government procurement procedures. However, public procurement in South Africa has been granted constitutional status and is recognised as a means of addressing past discriminatory policies and practices (Bolton, 2006: 193).

Reforms in public procurement in South Africa were initiated to promote the principles of good governance, and the National Treasury introduced a preference system to address socioeconomic objectives. The reform processes were due to inconsistency in policy application 
and the lack of accountability and supportive structures as well as fragmented processes. Matthee (2006: 65) asserted that a uniform implementation approach to procurement was required, due to a research study on opportunities for reform processes in the South African government (2000) conducted by the Joint Country Assessment Review (CPAR) and the World Bank in 2001. The deficiencies and fragmentations in governance, interpretation and implementation of the Preferential Procurement Policy Framework Act (PPPFA) Act No 5 of 2000, resulted in the introduction of supply chain management (SCM) in the public sector as a policy tool (National Treasury, 2005: 8). In 2003, a SCM document entitled 'Supply Chain Management: A guide for accounting officers/authorities' was developed to guide the adoption of the integrated SCM function and its related managerial responsibilities (National Treasury, 2005: 5). This was government's attempt to achieve the desired strategic policy outcomes through public procurement (McCrudden, 2004: 257).

Despite the reform processes in public procurement and the employment of SCM as a strategic tool, there are predicaments in South African public procurement practices, for example non-compliance with procurement and SCM-related legislation and policies as well as tender irregularities (Smart Procurement, 2011). According to De Lange (2011), 'Taxpayers were fleeced of R30 bn. Corruption, incompetence and negligence by public servants' were to be blamed. The South African government spent R26.4 billion in 2010 in ways that contravened laws and regulations (Smart Procurement, 2011).

Against this background, two very important questions can be asked:

1. What are the procurement challenges in the South African public sector?

2. How can public procurement in South Africa be improved?

Possible answers to these questions are discussed in the rest of this article.

\section{RESEARCH METHOD}

This article is of an exploratory nature and involves a conceptual analytical approach. Conceptual analysis is a technique that treats concepts as classes of objects, events, properties or relationships (Funer, 2004: 233). The technique involves defining the meaning of a given concept precisely by identifying and specifying the conditions under which any entity or phenomenon is (or could be) classified under the concept in question. Conceptual analysis is used in order to get a better understanding of procurement practices in the South African public sector. The study on which this article is based reviewed relevant literature sources on public procurement. Also, pertinent procurement policy documents from the National Treasury website, newspaper reports as well as other research documents relating to procurement in the South African public sector were reviewed and analysed. In light of the method discussed, the study examined: (1) the nature of public procurement, 
(2) public procurement practices in South Africa, (3) the challenges of public procurement in South Africa, and (4) the way forward for public procurement in South Africa.

\section{THE NATURE OF PUBLIC PROCUREMENT}

Public procurement has its origins in the fiduciary obligation of government administrations to deliver goods and infrastructure, for example roads and harbours and services, for example health care and education to the population of a country or a specific geographic region, city or town (Odhiambo \& Kamau, 2003: 10). Public procurement refers to the government activity of purchasing the goods and services needed to perform its functions (Arrowsmith, 2010: 1). According to Odhiambo and Kamau (2003: 10), public procurement is broadly defined as the purchasing, hiring or obtaining by any contractual means, goods, construction works and services by the public sector. It involves the purchase of commodities and contracting of construction works and services if such acquisition is effected with resources from state budgets, local authority budgets, state foundation funds, domestic loans or foreign loans guaranteed by the state, foreign aid and revenue received from the economic activity of state. According to Hommen and Rolfstam (2009), public procurement is 'the acquisition (through buying or purchasing) of goods and services by government or public organizations'. Arrowsmith (2010: 1) contends that the concept of public procurement can be referred to as procurement planning, contract placement and contract administration.

Based on the above discussion, public procurement can be defined as follows:

Public procurement is the function whereby public sector organisations acquire goods, services and development and construction projects from suppliers in the local and international market, subject to the general principles of fairness, equitability, transparency, competitiveness and cost-effectiveness. It includes many activities that support the service delivery of government entities, ranging from routine items to complex development and construction projects. It also directly or indirectly supports government's social and political aims.

Besides the fiduciary obligation to deliver goods and services to the constituents of the particular government administration, public procurement addresses a wide range of objectives (Uyarra \& Flanagan, 2009: 2). It has been used by governments to achieve socio-economic objectives such as stimulating economic activity; protecting national industries from foreign competition; improving the competitiveness of certain industrial sectors; and remedying national disparities (Bolton, 2006; Thai, 2006). The objectives of public procurement are achieved through various means, and legal and regulatory rules on conducting public procurement (Arrowsmith, 2010: 4).

Public procurement is the sheer volume of funds channelled through government procurement and is the largest single buyer in most countries (OECD, 2007: 1). The size of 
public procurement varies between $5 \%$ and $8 \%$ of the gross domestic product (GDP) in most industrialised countries (OECD, 2007: 1). In the Middle East and Africa, central government purchases range from 9\% to $13 \%$ (Gul, 2010: 1). This indicates that public procurement plays a vital role in a country (Odhiambo \& Kamau, 2003: 10). Public procurement has important economic and political implications, and ensuring that the process is economical and efficient is crucial. This requires in part that the whole procurement process should be well understood by the actors: government, the procuring entities and the business community/suppliers and other stakeholders, including professional associations, academic entities and the general public (Odhiambo \& Kamau, 2003: 10).

Public procurement is increasingly recognised as a profession that plays a key role in the successful management of public resources, and a number of countries have become increasingly aware of the significance of procurement as an area vulnerable to mismanagement and corruption and have thus made an effort to integrate procurement into a more strategic view of government efforts. As part of the efforts to adopt a longterm and strategic view of their procurement needs and management, most countries have resorted to using their annual procurement plans as a possible problem solver (Mahmood, 2010: 103).

After reviewing public procurement in general, the discussion now moves to public procurement in the South African public sector.

\section{PUBLIC PROCUREMENT IN SOUTH AFRICA}

Immediately after taking office in 1994, the new South African government initiated a series of budgetary and financial reforms on procurement. The intention of the procurement reforms was to modernise the management of the public sector, to make it more peoplefriendly and sensitive to meeting the needs of the communities it serves.

\section{Background to procurement reforms}

Procurement reforms in South Africa started in 1995 and were directed at two broad focus areas, namely the promotion of principles of good governance and the introduction of a preference system to address certain socio-economic objectives. The procurement reform processes were embedded in Section 112 of the Municipal Financial Management Act No 56 of 2003 (MFMA) and Section 76(4) (C) of the Public Finance Management Act No 1 of 1999 (PFMA) and the Preferential Procurement Policy Framework Act No 5 of 2000 (PPPFA). In 2001, the National Treasury completed a joint CPAR with the World Bank to assess procurement practices throughout the public sector. The CPAR identified certain deficiencies in the current practices relating to governance, interpretation and implementation of the PPPFA and its associated regulations (National Treasury, 2005). 
The systems of procurement and provisioning were fragmented owing to the fact that tender boards were responsible for procurement, whereas provisioning was largely underwritten by norms and standards in the logistics system driven by the National Treasury. Effective and efficient financial management in government was continuously questioned. Similarly, the logistics system as a tool for asset management raised concerns because of a lack of proper handling of movable assets in the government environment (Mkhize 2004: 4). The year 2003 saw the adoption of an SCM document entitled 'Policy to guide uniformity in procurement reform processes in government' in conjunction with provincial treasuries to replace the outdated procurement and provisional practices in municipalities. 'Supply chain management: a guide for accounting officers of municipalities and municipal entities' was also compiled to provide guidelines on the adoption of the integrated SCM function and its related managerial responsibilities assigned to accounting officers in terms of sections 62 and 95 of the MFMA. The guide explains how Chapter 11, part 1 of the MFMA, the municipal SCM regulations and the SCM policy of the council or board of directors can be adopted as an operational process for accounting officers to deal with each step of the SCM cycle. The principle behind the policy guide is that managers should be given flexibility to manage and ensure the constitutional requirements of transparency and accountability (National Treasury, 2005).

\section{Management of public procurement}

In South Africa, SCM is an important tool for managing public procurement. SCM is an integral part of prudent financial management in the South African public sectormanagement (OGC 2005: 11). According to Hanks, Davies and Perera (2008), SCM operates within a regulatory framework set by the national government and extended by provinces and local government bodies to specific policies, legislation and regulations. The aim of SCM is to add value at each stage of the procurement process - from the demand for goods or services to their acquisition, managing the logistics process, and finally, after use, to their disposal. In so doing, SCM aims to address deficiencies in current practice relating to procurement, contract management, inventory and asset control and obsolescence planning. Adoption of an SCM policy thus ensures uniformity in bid and contract documentation, and options and bid and procedure standards, inter alia, will promote the standardisation of SCM practices (National Treasury, 2003).

The National Treasury regulations reinforce the provisions of the PFMA and MFMA, finalise the devolution of the SCM function to the accounting officer, and formalise the integration of various functions into a single SCM function. The National Treasury regulations provide the broad legislative framework for SCM by:

- defining the various elements of SCM, such as demand management, acquisition management, logistics management, disposal management and SCM performance

- institutionalising the creation of a supply chain management unit in the office of the chief financial officer 
- specifying the roles of the accounting officer in the management of the bidding process

- providing for processes and procedures in the case of abuse of the supply chain management system within a department

- requiring the National and Provincial Treasury and municipal finance department to establish a system to collect and report on the performance of the SCM system within their defined jurisdictions (National Treasury, 2005).

The legislation and regulations outline minimum requirements in the areas of supply chain and preferential procurement. National departments and provincial and local governments are allowed to extend and develop their policies, systems and structures within the ambit of the national regulatory framework (Hanks et al., 2008). Hence, to a large extent, public procurement is decentralised to departments, provinces and municipalities. Based on this decentralised structure, the National Treasury regulation stipulates that organs of state should establish three kinds of committee: bid specification, bid adjudication and bid award committees. Through this process of segregation of duties, greater efficiency and risk management is promoted. Some departments have decided to combine the bid specification and adjudication committees (Pauw, 2011).

\section{Legislative framework for procurement}

Section 217 of the Constitution of the Republic of South Africa Act No 108 of 1996 stipulates the primary and broad secondary procurement objectives, as indicated in Table 1. Section $217(3)$ of the Constitution requires that national legislation prescribe a framework within which the preferential procurement policy must be implemented. The PPPFA was promulgated in response to this constitutional imperative. Procurement by organs of state (national and provincial departments, municipalities, constitutional entities and public entities) is also governed by a number of other pieces of legislation. Table 1 indicates the objective of procurement in South Africa as contained in the Constitution.

Table 1: Public procurement objectives in South Africa as set out in the Constitution

\begin{tabular}{|c|c|c|}
\hline Objective & & Reference \\
\hline Primary & $\begin{array}{l}\text { Procurement system to be fair, equitable, transparent, } \\
\text { competitive and cost effective }\end{array}$ & Section 217(1) \\
\hline Secondary & $\begin{array}{l}\text { Procurement policy may provide for: } \\
\text { 1. categories of preference in the allocation of contracts and } \\
\text { 2. the protection or advancement of persons, or categories of } \\
\text { persons, disadvantaged by unfair discrimination }\end{array}$ & Section $217(2)$ \\
\hline
\end{tabular}

Source: Pauw and Wolvaardt (2009, p.67); Bolton (2006, p.203); Watermeyer (2011, p.3) 
The PFMA (76[4] permits the National Treasury to make regulations or issue instructions applicable to all institutions to which the Act applies concerning 'the determination of a framework for an appropriate procurement and provisioning system which is fair, equitable, transparent, competitive and cost effective' (Watermeyer, 2011: 3). Also, the procurement provisions of the MFMA are similar to the provisions of the PFMA, but contain more detail on the system. Section 112 of the PFMA Act No 1 of 1999 permits the Minister of Finance to issue a prescribed regulatory framework for SCM that covers a number of specific issues. The SCM regulations issued in terms of the PFMA and MFMA Acts lay down the requirements for the governance of procurement processes and establish a high-level government policy. Each organ of state has to determine its own procedures and policies, which are consistent with the legislative framework (Watermeyer 2011: 3).

There are, therefore, numerous legislative frameworks that guide procurement practices. These include the:

- Constitution

- Public Finance Management Act 1 of 1999

- Municipal Finance Management Act No 56 of 2003

- Preferential Procurement Policy Framework Act No 5 of 2000

- Broad-based Black Economic Empowerment Act 53 of 2003

- Promotion of Administrative Justice Act No 3 of 2000

- Promotion of Equality and the Prevention of Unfair Discrimination Act No 4 of 2000

- Construction Industry Development Board Act No 38 of 2000

- Prevention and Combating of Corrupt Activities Act No 12 of 2004, and so on (Migiro \& Ambe, 2008).

Table 2 summarises the Acts and their functions in procurement practices in South Africa.

Table 2: Primary Acts that regulate procurement

\begin{tabular}{|l|l|}
\hline Act & What it does in respect of procurement \\
\hline $\begin{array}{l}\text { Public Finance } \\
\text { Management Act 1 } \\
\text { of 1999 }\end{array}$ & $\begin{array}{l}\text { Establishes a regulatory framework for SCM, which includes procurement in } \\
\text { national and provincial departments and state-owned enterprises. }\end{array}$ \\
\hline & $\begin{array}{l}\text { Establishes fair administrative procedures, permits those affected by unfair } \\
\text { administrative action to request reasons for such administrative action and } \\
\text { requires administrators to respond to such requests. (Administrative actions } \\
\text { are presumed to have been taken without good cause where an administrator } \\
\text { fails to respond within the prescribed period.) }\end{array}$ \\
$\begin{array}{l}\text { Promotion of } \\
\text { Administrative Justice } 3 \text { of 2000 }\end{array}$ & $\begin{array}{l}\text { Provides for procedures for the judicial review of administrative actions } \\
\text { and remedies in proceedings for judicial review, including the prohibition } \\
\text { of an administrator from acting in a particular manner, setting aside the } \\
\text { administrative action, correcting the defective action and ordering the } \\
\text { administrator to pay compensation. }\end{array}$ \\
\hline
\end{tabular}




\begin{tabular}{|c|c|}
\hline $\begin{array}{l}\text { The Promotion of } \\
\text { Equality and the } \\
\text { Prevention of Unfair } \\
\text { Discrimination Act } 4 \\
\text { of } 2000\end{array}$ & $\begin{array}{l}\text { Prohibits the state or any person from discriminating unfairly against any } \\
\text { person on the grounds of race or gender through the denial of access to } \\
\text { contractual opportunities for rendering services or by failing to take steps to } \\
\text { reasonably accommodate the needs of such persons. }\end{array}$ \\
\hline $\begin{array}{l}\text { Preferential Procurement } \\
\text { Policy Framework Act } 5 \\
\text { of } 2000\end{array}$ & $\begin{array}{l}\text { Establishes the manner in which preferential procurement policies are to be } \\
\text { implemented. }\end{array}$ \\
\hline $\begin{array}{l}\text { Construction Industry } \\
\text { Development Board Act } \\
38 \text { of } 2000\end{array}$ & $\begin{array}{l}\text { Establishes the means by which the Board can promote and implement } \\
\text { policies, programmes and projects, including those aimed at procurement } \\
\text { reform, standardisation and uniformity in procurement documentation, } \\
\text { practices and procedures within the framework of the procurement policy of } \\
\text { government, through the establishment of: } \\
\text { 1. a national register of contractors (and if required, consultants and suppliers) } \\
\text { to manage public sector procurement risk and facilitate public procurement; } \\
\text { 2. a register of projects above a financial value with data relating to contracts } \\
\text { awarded and completed and a best practice project assessment scheme; } \\
\text { 3. best practices } \\
\text { Establishes a code of conduct for the parties engaged in construction } \\
\text { procurement. }\end{array}$ \\
\hline $\begin{array}{l}\text { Broad-based Black } \\
\text { Economic } \\
\text { Empowerment } \\
\text { Act } 53 \text { of } 2003\end{array}$ & $\begin{array}{l}\text { Establishes a code of good practice to inform the: } \\
\text { - development of qualification criteria for the issuing of licences or } \\
\text { concessions, the sale of state-owned enterprises and for entering into } \\
\text { partnerships with the private sector; and } \\
\text { - development and implementation of a preferential procurement policy. }\end{array}$ \\
\hline $\begin{array}{l}\text { Local government: } \\
\text { Municipal Finance } \\
\text { Management Act } 56 \\
\text { of } 2003\end{array}$ & $\begin{array}{l}\text { Establishes a regulatory framework for SCM which includes procurement in } \\
\text { municipalities and municipal entities. }\end{array}$ \\
\hline $\begin{array}{l}\text { Prevention and } \\
\text { Combating of Corrupt } \\
\text { Activities Act } \\
12 \text { of } 2004\end{array}$ & $\begin{array}{l}\text { Makes corruption and related activities an offence; establishes a Register } \\
\text { in order to place certain restrictions on persons and enterprises convicted } \\
\text { of corrupt activities relating to tenders and contracts; and places a duty } \\
\text { on certain persons holding a position of authority to report certain corrupt } \\
\text { transactions. }\end{array}$ \\
\hline
\end{tabular}

Source: Adapted from Watermeyer (2011: 3)

Having dwelt on the status of public procurement in South Africa, the focus of the discussion now turns to the challenges faced with the implementation procurement in the South African public sector.

\section{PUBLIC PROCUREMENT CHALLENGES IN SOUTH AFRICA}

It is important to note that SCM is an integral part of procurement in the South African public sector. Therefore, it is used as a tool for the management of public procurement practices. However, despite the employment of SCM as a strategic tool, public procurement in South Africa still faces enormous predicaments. These include, among others:

- lack of proper knowledge, skills and capacity

- non-compliance with SCM policy and regulations 
- inadequate planning and the linking of demand to the budget

- accountability, fraud and corruption

- inadequate monitoring and evaluation of SCM

- unethical behaviour

- too much decentralisation of the procurement system

- ineffectiveness of the black economic empowerment (BEE) policy.

These predicaments are briefly discussed below.

\section{Lack of proper knowledge, skills and capacity}

To fully achieve SCM objectives, the National Treasury provides support by facilitating the development of appropriate training materials to government departments, municipalities and municipal entities (National Treasury, 2005). However, the shortage of skills has been a re-concurrent theme in public discussion. According to Sheoraj (2007), skills and capacity shortages have been identified as the single greatest impediment to the success of public procurement in South Africa. Adequate capacity in the form of appropriate structures with fully skilled and professional SCM personnel is a key success factor for proper SCM implementation. In some government entities, the quality of SCM personnel's skills and ability are well below standard. Migiro and Ambe (2008) assert that many SCM actors in the South African public sphere have attended a number of training workshops on $\mathrm{SCM}$, but they still lack the appropriate knowledge for proper implementation. McCarthy (2006) contends that there is a lack of capacity and knowledge by SCM actors to handle procurement processes that have led to bad governance. The South African government embarks on programmes that educate practitioners, but implementation of its programmes always falls short.

\section{Non-compliance with policies and regulations}

SCM is guided by a number of related policies and regulations (National Treasury, 2005). Compliance with these policies and regulations is a problem. As indicated by Matthee (2006), some of the practices relating to non-compliance with the rules and procedures relate to the tendency not to utilise a competitive process for both quotations and bids, and incorrect utilisation of the preference points system. Van Zyl (2006) also asserts that there is a lack of appropriate bid committees; use of unqualified suppliers, passing over of bids for incorrect reasons; utilisation of the incorrect procurement process in respect of the thresholds; extensions of validity periods; and incorrect utilisation of the limited bidding process. Furthermore, Ambe and Badenhorst-Weiss (2011b) noted that there are inadequate controls and procedures for the handling of bids; appointment of bid committee members not aligned to policy requirements; and insufficient motivation for deviations from SCM procedures. 


\section{Inadequate planning and linking demand to the budget}

Demand management is integral to the SCM process. It defines the decision-making process that allows departments to procure at the right time, at the right place and at the right cost. However, many government entities are still faced with the challenges of improper planning and linking demand to budget (Ambe \& Badenhorst-Weiss, 2011a). Cost-effective procurement depends on a specialist's skills to ensure that buying requirements are reliably determined, appropriate contract strategies are developed, contracts are well managed and opportunities are seized to secure the best deals at the right time and at the right price. The importance of drawing up accurate and realistic strategic plans cannot be overestimated. At times there is an absence of coherent plans. Some government entities cannot properly quantify the needs of those requiring their services or properly estimate costs, nor can they accurately track, control or report on expenditure (Luyt, 2008). Luyt (2008) indicates that there is a need to monitor the delivery of services properly to ensure that scarce resources are efficiently and effectively procured. Poor planning and budgeting have also affected the implementation of SCM. It is therefore vital that SCM practitioners adequately link demand planning to budget.

\section{Accountability, fraud and corruption}

Accountability constitutes a central pillar to public procurement (Soudry, 2007). Without transparent and accountable systems, the vast resources channelled through public procurement systems run the danger of being entangled with increased corruption and misuse of funds (Jeppesen, 2010). According to Mahlaba (2004), fraud and corruption cost South African tax payers hundreds of millions of rand each year. Over the last few years, the impact of fraud has led to the promulgation of special legislation and improvement in existing legislation that led to the creation, among others, of the Directorate of Special Operations, commonly known as the Scorpions, the Asset Forfeiture Unit, the Public Protector, the Special Investigation Unit, Commercial Crime Units, Internal Audit Units, Special Investigation Units within departments, and the appointment of forensic consultants (Mahlaba, 2004).

According to Boateng (2008), since 1994, South Africa has enjoyed unprecedented social and infrastructural programmes. Yet, the majority of people who had hoped freedom would bring with it relative socio-economic liberation and improvement are feeling increasingly bitter towards government over issues that include a lack of perceived quality of governance, service delivery failure, fraud and corruption in some spheres of the economy and disillusionment with empowerment policies (De Lange, 2011). The Public Service Commission Committee (2011) indicated that a total of 7766 corruption cases had been reported through the National Anti-Corruption Hotline since its inception in September 2004 up till June 2010. De Lange (2011) notes that taxpayers were fleeced of R30 billion (3.675 billion USD). Corruption, incompetence and negligence by public servants were 
to be blamed (De Lange, 2011). About 20 per cent of government's procurement budget alone 'went down the drain each year. This was because officials had their fingers in the till, overpaid for products and services or failed to monitor how money was spent' (De Lange, 2011). Among government entities probed for procurement irregularities was the Tshwane Metro where about 65 municipal officials were investigated for striking business deals worth about R185 million with their own Council (Pauw, 2011). The National and Provincial governments and their entities notched up R21 billion in irregular expenditure in 2010, a 62\% rise (R13 billion) over the previous year (De Lange, 2011). The auditor general highlighted weaknesses in SCM, controls over information technology, human resource management, and capital assets and performance reporting during a briefing to Parliament's Standing Committee on Public Account (Smart Procurement, 2011).

Hence, there is an urgent need to rethink innovative ways of curbing corruption and some other administrative malpractices within South African spheres of government. To fight the scourge of maladministration, mismanagement of finances, fraud and corruption, government needs to strengthen and review existing internal control systems to detect deficiencies.

\section{Inadequate measures for monitoring and evaluation of SCM}

Effective policy-making requires information on whether governments are doing things right and whether they achieve the results intended (Acevedo, Rivera, Lima \& Hwang, 2010). Strong monitoring and evaluation systems provide the means to compile and integrate this valuable information into the policy cycle, thus providing the basis for sound governance and accountable public policies (Acevedo et al., 2010). Inadequate monitoring and evaluation is linked to the absence or the poor presence of a control environment, and the government entities are placed in a difficult position to give effect to or implement SCM as required by the policy. Hence, deviations or non-compliance goes undetected or is identified after the fact. According to a Business Day report (2011), procurement actors in government have spent millions of rand in ways that contravened laws and regulations. The national and provincial governments and their entities have notched irregular, unauthorised, fruitless and wasteful expenditures that contravene laws and regulations. There is lack of proper monitoring and evaluation as required (Stemele, 2009).

\section{Unethical behaviour}

Ethics is the study of moral judgements and right and wrong conduct. Ethics and conflict of interest greatly affect SCM implementation. Enormous power is wielded by some chief financial officers but there is also a lack of proper consultation with other senior officials. While the National Treasury's guide to accounting officers prescribes a standard approach towards SCM procedure, in many instances there is lack of compliance and application of the guidelines. This has resulted in differentiation in approaches and a lack of standardisation. According to McCarthy (2006), the completeness of tender documents in many municipalities is difficult to verify. 


\section{Too much decentralisation of the procurement system}

In South Africa, government procurement of own or local requirements (materials, equipment and services) is to a large extent decentralised to departments, provinces and municipalities. If one takes the number of cases of tender fraud and lack of services on all levels of government into account one should ask oneself whether these parties have the knowledge and/or the intention to get the best value for tax-payers' money. Arguments for a larger extent of centralisation of procurement to knowledgeable, accountable procurement officials/agents or procurement consortiums could be put forward.

'Centralization leverages scales to reduce costs. Decentralisation relies on local knowledge to build relationships' (Fawcett, Ellram \& Ogden, 2007: 310). Centralisation offers advantages such as leverage due to volumes, reduction of duplication of purchasing effort, better control and development of specialised expertise of purchasing personnel (Handfield, Monczka, Guinipero \& Patterson, 2011: 160-61). On the other hand, decentralisation often leads to better responsiveness to purchasing needs, a better understanding of unique local needs, and is closer to suppliers and taking ownership of decisions that impact on one's own budget (Handfield et al. 2011: 162). However, if the advantages of centralisation are to be realised, efficient contract management and supplier relationship management is a pre-condition. The schoolbook saga in various provinces of South Africa in 2012, where textbooks had not been delivered to schools by the third term of the school year is an example of what can happen without proper contract management.

\section{Ineffectiveness of broad-based black economic empowerment}

The South African government adopted the provision of BEE to empower all historically disadvantaged people rather than only a small group of black investors. To this end, it adopted the Broad-Based Black Economic Empowerment Act (BBBEEA), which calls for expanded opportunities for workers and smaller enterprises as well as more representative ownership and management. Current BEE provisions have, however, in many instances failed to ensure a broad-based approach, instead imposing significant costs on the economy without supporting employment creation or growth. The present BEE model remains excessively focused on transactions that involve existing assets and which benefit a relatively small number of individuals. The following shortcomings have emerged in the implementation of BEE: First, ownership and senior management issues receive disproportionate emphasis. The unintended consequences of this trend include 'fronting', speculation and tender abuse. Secondly, the regulations do not adequately incentivise employment creation, support for small enterprises and local procurement. The preferential procurement regulations aggravate this situation by privileging ownership over local production. Finally, the BBBEE regulations penalise public entities as suppliers. The democratic state owns public entities on behalf of its people yet the regulations do not count them as 'black empowered' (Zuma, 2009). 
Subsequent to the discussion presented above, it is evident that there are constraints in procurement practices in the South African public sector. These predicaments can to a large extent be attributed to lack of proper knowledge, skills and capacity. Therefore, the South African government will need to address these dilemmas in order to fully achieve the policy objective of public procurement.

\section{THE WAY FORWARD FOR PUBLIC PROCUREMENT IN SOUTH AFRICA}

There are a number of issues that could be considered to enhance procurement in the South African public sector. Therefore, it is critical that policy- and decision-makers consider developing skills and knowledge through specialised training programmes, involve stakeholders in the bidding process and employ centralisation and decentralisation for different categories of goods and services as discussed below.

\section{Developing skills and knowledge through teaching a two-model curriculum}

Institutions of higher learning and other service providers have a critical role to equip learners and practitioners with appropriate skills and knowledge. The capacity for qualified practitioners would only be available when educational institutions contribute to the challenge by way of developing a curriculum that meets the needs of the country. Such programmes should provide for an understanding of the knowledge of the South African public sector and its regulations.

Figure 1 illustrates an example of a two-model curriculum where learners have a choice to focus on the private or public sector. In this model, the skills required are general procurement skills and industry-specific skills. The private sector-oriented, programme-specific skills require an understanding of the general business environment (enterprise management), while the public sector-oriented programme concentrates on the legislative environment (to sensitise learners to an integrated approach in the management of procurement within the highly regulated public sector environment). Both programmes require general procurement skills which should include, among others, the knowledge of and insight into the purchasing and supply environment, sourcing strategies, purchasing and supply tasks, integrated supply management, globalisation, and technological advancement. Figure 1 illustrates a framework for a two-model curriculum for procurement in South Africa. 


\begin{tabular}{|c|c|c|c|c|c|}
\hline \multicolumn{2}{|c|}{$\begin{array}{l}\text { Private sector-oriented } \\
\text { Objective: Profit maximisation }\end{array}$} & & & \multicolumn{2}{|c|}{$\begin{array}{l}\text { Public sector-oriented } \\
\text { Objective: Quality service delivery }\end{array}$} \\
\hline & Enterprise management & \multicolumn{2}{|c|}{ Sector-specific skills } & \multirow{2}{*}{$\begin{array}{l}\text { - Public financial } \\
\text { management } \\
\text { - Public procurement and } \\
\text { supply chain management }\end{array}$} & \multirow{3}{*}{ 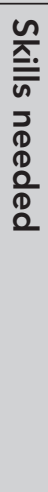 } \\
\hline & & $\begin{array}{l}\text { Knowledge on } \\
\text { the business } \\
\text { environment }\end{array}$ & $\begin{array}{l}\text { Knowledge on } \\
\text { the SA public } \\
\text { procurement } \\
\text { environment }\end{array}$ & & \\
\hline 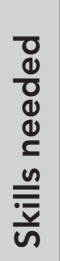 & $\begin{array}{l}\text { - Purchasing and supply } \\
\text { management } \\
\text { - Purchasing and supply tools } \\
\text { - Legal aspects in purchasing } \\
\text { - Storage and inventory } \\
\text { management }\end{array}$ & \multicolumn{2}{|c|}{$\begin{array}{l}\text { General procurement } \\
\text { management }\end{array}$} & $\begin{array}{l}\text { - Purchasing and supply } \\
\text { management } \\
\text { - Purchasing and supply tools } \\
\text { - Legal aspects in purchasing } \\
\text { - Storage and inventory } \\
\text { management }\end{array}$ & \\
\hline
\end{tabular}

Figure 1: Two-model teaching curriculums

\section{Stakeholders' involvement}

Public procurement malpractices could be limited through the employment of stakeholders such as civil society organisations to be part of the procurement process. The current status of the procurement system requires the creation of three bid committees, namely the bid specification committee, the evaluation committee and the adjudication committee. For the purpose of compliance and to minimise unethical and corrupt practices, stakeholders should be involved in the evaluation and adjudication process. This will ensure and support open governance. Open governance creates the conditions for effective collaboration between governments and citizens in a process that enhances legitimacy and accountability of public decision-making.

Stakeholder involvement will also encourage public servants to be more deliberate about decisions they make and will provide citizens as well as stakeholders with the opportunity to hold their leaders accountable. It will improve the efficiency of government institutions, reduce fraud and waste of public finances, strengthen the management of natural resources and ensure better service delivery.

\section{Strategic sourcing (centralisation versus decentralisation)}

Another improvement strategy for public procurement is the use of centralised and decentralised procurement strategies for different categories of goods and services. There are many arguments for centralisation, specifically better control and expertise. However, the answer for poor public procurement practices should rather be sought in strategic sourcing. An analysis of public procurement requirements at all levels of government should be done and high risk-low cost items (known as bottleneck items) and high risk-high cost items (strategic items) should be purchased on a centralised basis with longer-term contracts and high levels of contract and supplier management. Leverage items that are 
low risk but high cost can be purchased through one agency, for example a procurement consortium. The different public institutions then order from the contractor/supplier against a contract, typically through e-procurement, and distribution takes place on a decentralised basis. Here, contract management, and particularly feedback on supplier performance, is essential for this type of purchasing to be efficient. Non-critical, low risk-low cost items (also known as routine items) can be purchased on a decentralised basis by means of quotations from local suppliers (Simchi-Levy, Kaminksi \& Simchi-Levy, 2009: 287).

Over and above the proposed recommendation, it is important that departments, municipalities and municipal entities engage with the employment of qualified procurement practitioners, training and employment of internship programmes, development of an effective monitoring and evaluation tool, creation of incentive programmes to motivate good performance, tools (information communication technology) and also good leadership (Ambe \& Badenhorst-Weiss, 2011b).

\section{CONCLUSION}

Within the framework of a conceptual analytical approach, an examination of relevant literature and public procurement practices, challenges faced by the South African public sector is discussed in this article. Public procurement is increasingly recognised as a key concept that plays a significant role in the successful management of public resources. For this reason, several countries have become more aware of the importance of procurement as an area vulnerable to mismanagement and corruption, and have thus instituted efforts to integrate procurement in a strategic position of government efforts. As part of the need to adopt a long-term and strategic view of their procurement and management, most countries have resorted to turning to their annual procurement plans as a possible 'problem-solver' (Mahmood, 2010).

Public procurement primarily aims to be fair, equitable, transparent and cost-effective. Because of its importance, it can also be used at a secondary level as a problem solver. Due to the huge problems faced in South Africa, especially because of the country's inequality in the past, public procurement is of particular significance and has been granted constitutional status (Bolton, 2006). In this regard, there are categories of preference in the allocation of contracts as well as the protection or advancement of persons, or categories of persons, disadvantaged by unfair discrimination.

In South Africa, SCM is an integral part of the procurement process. It is a policy tool used in the management of the procurement process. Despite the importance of procurement as a policy tool, and the effort by government through the introduction of programmes such as SCM, procurement remains challenging in South Africa. These challenges include 
among others lack of proper knowledge, skills and capacity; non-compliance to the national treasury policies and regulations; inadequate planning and linking of demand to the budget; lack of proper accountability; fraud and corruption; inadequate response to and inconsistency in risk management/irregularities in $\mathrm{SCM}$; inadequate measures for monitoring and evaluation of $\mathrm{SCM}$; unethical behaviour; too much decentralisation and ineffectiveness of the BBBEE policy.

Against this background, it is evident that public procurement practitioners in South Africa require specific knowledge about the procurement objective, SCM policy, preference procurement policies and so forth in order to manage the procurement process effectively. Specialised training programmes are therefore required to equip actors with the skills to achieve procurement objectives. Key issues such as employment of qualified procurement practitioners, training and employment of learnership programmes, development of an effective monitoring and evaluation tool, and the creation of incentive programmes to motivate good performance should be employed. In addition, institutions of higher learning and other service providers should equip learners and practitioners with appropriate skills and knowledge through the development of a syllabus that ensures sustainable procurement in South Africa. In addition, it is important to involve stakeholders in the bidding process and employ centralisation and decentralisation for different categories of goods and services. 


\section{REFERENCES}

Acevedo, G.L., Rivera, K., Lima, L. \& Hwang, H. 2010. Challenges in monitoring and evaluation: an opportunity to institutionalize M\&E systems. Washington, DC: The International Bank for Reconstruction and Development/The World Bank.

Ambe, I.M. \& Badenhorst-Weiss, J.A. 2011a. An exploration of public sector supply chains with specific reference to the South African situation. Journal of Public Administration, 46(3):1100-15.

Ambe, I.M. \& Badenhorst-Weiss, J.A. 2011b. An examination of supply chain management in the South African public sector. 20th Annual IPSERA 2011 Conference, 10-14 April, Maastricht, The Netherlands.

Arrowsmith, S. 2010. Public procurement: Basic concepts and the coverage of procurement rules, in Public procurement relations: an introduction. EU Asia InterUniversity Network.

Boateng, D. 2008. Government service delivery lies in supply chain management, not centralised procurement, smart procurement. Available from: www.smartprocurement. co.za (accessed on 10 February 2012).

Bolton, P. 2006. Government procurement as a policy tool in South Africa. Journal of Public Procurement 6(3):193-217.

Business Day. 2011. Irregular state expenditure jumps 62\%. Smart Procurement. Available from: www.smartprocurement.co.za/achives/irregular_state_enpenditure_62.p (accessed on 10 February 2012).

Cane, P. 2004. Administrative law. 4th edition. London: Oxford University Press.

De Lange S. 2011. Irregular State Expenditure Jumps 62\%. Business Day (accessed on 20 October 2011).

Eyaa, S. \& Oluka, P.N. 2011. Explaining noncompliance in public procurement in Uganda. International Journal of Business and Social Science. 2(11), June:35-44.

Fawcett, S.E., Ellram, L.M. \& Ogden, J.A. 2007. Supply chain management - from vision to implementation. Upper Saddle River, Pearson Prentice-Hall.

Funer, J. 2004. Conceptual analysis: A method for understanding information as evidence, and evidence as information. Archival Science, 4:233-65. 
Gul, H. 2010. Modernising public procurement and creating an independent public procurement regulatory authority. Law transition online.

Handfield, R.B., Monczka, R.M., Guinipero, L.C. \& \& Patterson, J.L. 2011. Sourcing and supply chain management. USA, 5 th ed. South-Western Cengage Learning.

Hanks, J., Davies, H. \& Perera, O. 2008. Sustainable Public Procurement in South Africa. [Online]. Available at www.iisd.org (accessed on 30 May 2012).

Hommen, L., \& Rolfstam, M. 2009. Public procurement and innovation: Towards taxonomy. Journal of Public Procurement, 9(1):17-56.

Jeppesen R. 2010. Accountability in public procurement - transparency and the role of civil society. United Nations Procurement Capacity Development Centre. [Online]. Available at www.unpcdc.org (accessed on 7 March 2012).

Larson, P.D. 2009. Public vs private sector perspectives on supply chain management. Journal of Public Procurement 9(2):222-47.

Luyt, D. 2008. Media and Advocacy Head of the Public Service Accountability Monitor (PSAM), at the Monitor (PSAM). Paper Presented at the United Nations Social Forum on 2 September 2008 in Geneva, Switzerland.

Mahlaba, P.J. 2004. Fraud and corruption in the Public Sector: An audit perspective. S D R, 3(2):84-87.

Mahmood, S.A.I. 2010. Public procurement and corruption in Bangladesh: confronting the challenges and opportunities. Journal of Public Administration and Policy Research 2(6):103-11.

Matthee, C.A. 2006. The potential of internal audit to enhance supply chain management outcomes. Master's dissertation, University of Stellenbosch, Stellenbosch.

McCarthy, N.G. 2006. Report of the Auditor-General, Free State, Bloemfontein, 30 June:1-7.

McCrudden, C. 2004. Using public procurement to achieve social outcomes. Natural Resources Forum: 257-67.

Migiro, S.O. \& Ambe, I.M. 2008. Evaluation of the implementation of public sector supply chain management and challenges: a case study of the central district municipality, North West province, South Africa. African Journal of Business Management, 2(12):230-42. 
Mkhize, Z. 2004. Supply Chain Management Conference: Transforming Government Procurement System. Paper presented at the Supply Chain Management Conference, 2223 Nov, Durban, Republic of South Africa.

National Treasury. 2003. Policy strategy to guide uniformity in procurement reforms processes in government. Republic of South Africa.

National Treasury. 2005. Supply chain management: A guide for accounting officers and municipal entities. Republic of South Africa.

NT, vide National Treasury.

Odhiambo, W. \& Kamau, P. 2003. Public procurement: Lessons from Kenya, Tanzania and Uganda. OECD Development Centre Working Paper No. 208.

OECD. 2007. SIGMA support for improvement in governance and management. Available at: http://sigmaweb.org (accessed on 20 January 2012).

Office of Government of Commerce (OGC). 2005. Supply chain management in public sector procurement: a guide version, 6 June.

OGC, vide Office of Government of Commerce.

Pauw, J.C. 2011. Public procurement and supply chain management. Study Guide, programme in Public Procurement and Supply Management. Pretoria, South Africa: Centre for Business Management, University of South Africa.

Pauw, J.C. \& Wolvaardt, J.S. 2009. Multi-criteria decision analysis in public procurement - a plan from the South. Politeia, 28(1):66-88.

Public Service Commission. 2011. Report on profiling and analysis of the most common manifestations of corruption and its related risks in the public service. Republic of South Africa, Pretoria: Silowa Printers.

Sheoraj, R. 2007. The state of skills readiness in the South Africa public service: an overview of provincial and local government. Master's thesis, University of Pretoria, South Africa.

Simchi-Levy, D., Kaminksi, P. \& Simchi-Levy, E. 2009. Designing and managing the supply chain: Concepts, strategies and case studies. 3rd ed, New York, McGraw-Hill.

Smart Procurement. 2011. SA public procurement: poor value for money. Available from: www.smartprocurementworld.com (accessed on 10 February 2012). 
Soudry, O. 2007. A principal-agent analysis of accountability in public procurement. In Gustavo Piga \& Khi V. Thai (Eds.), Advancing Public Procurement: Practices, Innovation and Knowledge-Sharing (pp. 432-51). Boca Raton, FL: PrAcademics Press.

Stemele, BM. 2009. Assessing good governance in procurement at Lejweleputswa District Municipality. Master's dissertation. University of Stellenbosch.

Thai, K.V. 2006. Advancing public procurement: practices, innovation and knowledge sharing, in Advancing public procurement: practices, innovation and knowledge sharing (ch. 1), edited by K.V. Thai \& G. Piga:Pr Academics Press:1-13.

Uyarra, E. \& Flanagan, K. 2009. Understanding the innovation impacts of public procurement. Manchester Business School Working Paper, No. 574. Available at: http://www.mbs.ac.uk/ research/workingpapers/ (accessed on 19 January 2012).

Van Zyl, D.C. 2006. Strategic supply chain management by Matatiele Municipality. Master's dissertation, University of Stellenbosch, Stellenbosch.

Watermeyer, R.B. 2011. Regulating public procurement in Southern Africa through international and national standards. Public procurement regulation in Africa Conference, 25 October, Stellenbosch.

Zuma, J. 2009. The New Growth Path: The Framework. Inaugural State of the Nation Address. Pretoria, South Africa.

\section{Table of acronyms}

\begin{tabular}{|l|l|}
\hline BBBEE & Broad-Based Black Economic Empowerment \\
\hline BBBEEA & Broad-Based Black Economic Empowerment Act \\
\hline BEE & Black Economic Empowerment \\
\hline CPAR & Joint Country Assessment Review \\
\hline GDP & Gross Domestic Product \\
\hline MFMA & Municipal Financial Management Act No 56 of 2003 \\
\hline PFMA & Public Finance Management Act No 1 of 1999 \\
\hline PPPFA & Preferential Procurement Policy Framework Act \\
\hline SCM & Supply Chain Management \\
\hline
\end{tabular}

